\title{
EFFECT OF DIETARY SUPPLEMENTATION OF POMEGRANATE PEEL POWDER AND BUTYLATED HYDROXY TOLUENE ON SOME PRODUCTIVE, PHYSIOLOGICAL AND IMMUNOLOGICAL PARAMETERS OF JAPANESE QUAIL
}

\author{
Doaa M.M. Yassein, E. A. Abdallah, Inas I. Ismail ${ }^{*}$ and A.A. Faddle \\ Animal Production Research Institute, Agricultural Research Center, Egypt \\ *Corresponding author. E-mail: drinas53@hoatmail.com, Tel: (+2) 01155833005
}

\section{SUMMARY}

This experiment aimed to study the effect of pomegranate peel powder (PPP) and butylated hydroxy toluene (BHT) on some productive, physiological and immunological parameters of Japanese quails. One hundred and eighty Japanese quails aged 11 weeks old were randomly divided into four treated groups, each group contain 3 replicates 15 bird each. The first group was fed control diet without any supplementation. While, the second and third groups were fed on diet containing 10 and $15 \mathrm{~g} P P P / \mathrm{kg}$ respectively, and the fourth group were fed on diet containing $125 \mathrm{~g} / \mathrm{ton}$ BHT. The results indicated that: 1- Pomegranate peel treatments powder significantly increased body weight gain, while, feed intake and feed conversion were significantly lower in all treated groups compared with control group. 2-Egg production traits (egg number, egg weight and egg mass) were significantly increased in PPP and BHT supplemented groups compared to control. 3-Egg shell weight was significantly higher in treated groups. While, yolk diameter was significantly longer in control than treated groups. While, yolk color and albumin were higher at (22 wks. of age). 4-Plasma total lipid TP, Cholesterol, low density lipoprotein $L D L$ and high density lipoprotein $H D L$, creatinine, uric acid, AST and ALT significantly decreased by PPP addition. While, plasma TP was significantly increased in PPP and BHT treated groups. 5-Deftherdbody weight after slaughter was significantly increased in groups fed on $10 \mathrm{PPP} \mathrm{g} / \mathrm{kg}$ diet. While, heart percentage of weight was significantly lowered in quails supplemented with $15 \mathrm{~g}$ PPP $/ \mathrm{kg}$ diet. 6-Supplementation of PPP and BHT didn't affect the total micro bacterial count in instant. 7-Total phenolicswere significantly increased. While, the TBARS values was significantly decreased in birds fed $15 \mathrm{~g} P P P / \mathrm{kg}$ compared with that received BHT supplemented diet and the control group. In conclusion, PPP addition by $15 \mathrm{~g} P P P / \mathrm{kg}$ diet can improve productive and physiological parameters and also can extend meat shelf-life.

Keywords: Butylated hydroxy toluene - Japanese quails- pomegranate peel powder

\section{INTRODUCTION}

Antioxidants play a major role in poultry performance due to the prevention of oxidative destruction of dietary fats and to provide enhanced protection for the longer chain polyunsaturated fatty acid. Many studied investigate the waste of pomegranate different parts as peel, seeds and leaf extracts the antioxidant capacity was respectively 55.3, 35.7 and $16.4 \%$. Therefore, it seems that high antifungal and antioxidant activity of peel and seeds of pomegranate due to the high percentage of phenolic compounds in these plant parts extracts (Salahvarzi et al., 2011). In addition, pomegranate peel extract with an abundance of flavonoids and tannins has been shown to have a high antioxidant activity (Abdel Moneim et al., 2011). Pomegranate peel extract have more potential as a health supplement rich in natural antioxidants than the pulp extract (Li et al., 2006). Negi et al. (2003) studied the polyphenolic compounds in pomegranate peel (PP) as it is a natural source of such as ellagic tannins, ellagic acid and gallic acid. Negi and Jayaprakasha (2003) studied the action of phenolics as an antioxidant by donating electrons and reacting with free radicals to convert them to more stable products and terminate free radical chain reactions. Some studies showed the medical effect of pome granate on immune system Gracious Ross et al. (2011) found that $100 \mathrm{mg} / \mathrm{kg}$ Punic agranatum fruit rind powder (PGFRP) orally stimulate the cell-mediated and humoral components and increasing antibody titer to typhoid-H antigenin rabbits. Also, inhibit antimicrobial activity Yahia et al. (2011).

Synthetic antioxidants have been widely used as food or feed preservatives because oft heir low cost and effectiveness. The most common used synthetic antioxidants, butylated hydroxyl anisole (BHA) and butylated hydroxyl toluene (BHT). European Food Safety Authority, (2012) mentioned that BHT (E 321) authorised as a food additive in the EU that was previously evaluated by the EU Scientific Committee for Food (SCF) in 1987 and the Joint FAO/WHO Expert 
Committee on Food Additives (JECFA) several times, the latest in 1996.

Natural phenolic antioxidants in vegetables and fruits had strong activity and low toxicity compared with those of synthetic phenolic antioxidants, such as butylated hydroxyl toluene (BHT) (Marinova and Yanishlieva, 1997).

The main target of this study was to evaluate the effect of adding pomegranate peel powder (PPP) as natural antioxidants compared with BHT as a synthetic antioxidant to Japanese quails diets on productive performance, egg quality traits, physiological and immunological parameters.

\section{MATERIAL AND METHODS}

\section{Experimental birds and treatments:}

The present study was carried out at Fayiom Animal Research Station, Animal Production Research Institute, Ministry of Agriculture,
Egypt. The chemical analyses were carried out at Laboratories of the Animal Production Research Institute (APRI), Ministry of Agriculture, Egypt. Ground PPP was obtained from Dokki Market, Giza Governorate, Egypt. The PPP was obtained in dried form with moisture content of $9-10 \%$. Butylated Hydroxy Toluene (BHT) was obtained from poultry breeding laboratory (APRI). A total number of 180 one day old Japanese quails were randomly divided into four treated groups, each group contain 3 replicates 15 bird each. The first was served as control. While, the second and third groups were fed on diet containing 10 and $15 \mathrm{~g} \mathrm{ppp} / \mathrm{kg}$ and the fourth group were fed on diet containing $125 \mathrm{~g} / \mathrm{ton}$ Butylated Hydroxy Toluene (BHT) as shown in Table (1).All birds were fed ad.libitum, body weight and feed intake were measured daily, data on Table (2) showed the chemical composition of pomegranate peel (dried and fresh base).

Table 1. Composition and calculated analysis of the quail's diet

\begin{tabular}{|c|c|c|c|c|}
\hline \multirow{2}{*}{ Ingredients } & \multicolumn{4}{|c|}{ Treatments } \\
\hline & T1 (Control) & T2(10ppp) & T3(15ppp) & T4(BHT) \\
\hline Yellow corn & 58.45 & 58.45 & 58.45 & 58.45 \\
\hline Soyabeen meal $44 \%$ & 25.80 & 25.80 & 25.80 & 25.80 \\
\hline Corn glutten meal $62 \%$ & 6.70 & 6.70 & 6.70 & 6.70 \\
\hline Vegetable oil & 1.30 & 1.30 & 1.30 & 1.30 \\
\hline Dicalcium phosphate & 1.10 & 1.10 & 1.10 & 1.10 \\
\hline Limestone & 5.70 & 5.70 & 5.70 & 5.70 \\
\hline Common salt ( $\mathrm{NaCl})$ & 0.34 & 0.34 & 0.34 & 0.34 \\
\hline Premix $* * / k g$ & 0.30 & 0.30 & 0.30 & 0.30 \\
\hline dl-Methionine & 0.05 & 0.05 & 0.05 & 0.05 \\
\hline L-Lysine & 0.06 & 0.06 & 0.06 & 0.06 \\
\hline Choline chloride & 0.20 & 0.20 & 0.20 & 0.20 \\
\hline $\begin{array}{l}\text { Pomegranate peel powder } \\
(\mathrm{g} / \mathrm{kg})\end{array}$ & - & 10.00 & 15.00 & - \\
\hline \multirow{2}{*}{$\begin{array}{l}\text { Butylated Hydrox Toluene } \\
\text { (BHT) g/ton }\end{array}$} & - & - & - & 125 \\
\hline & \multicolumn{4}{|c|}{ CALCULATED analysis* } \\
\hline C.P\% & \multicolumn{4}{|c|}{20.01} \\
\hline ME (kcal/kg) & \multicolumn{4}{|c|}{2890} \\
\hline C.A\% & \multicolumn{4}{|c|}{2.5} \\
\hline C.F\% & \multicolumn{4}{|c|}{3.36} \\
\hline A.v phosphorus & \multicolumn{4}{|c|}{0.35} \\
\hline \multicolumn{5}{|c|}{$\begin{array}{l}\text { **premix: Supplied per kg diet: Vit. A, } 7040 \mathrm{IU} \text {; Vit.D3, } 2000 \mathrm{IU} \text {; Vit. E, } 8.8 \mathrm{IU} \text {; Vit. K3, } 1.76 \mathrm{mg} \text {; Biotin, } 0.12 \\
\text { mg; Thiamine, } 1.2 \mathrm{mg} \text {; Riboflavin, } 3.2 \mathrm{mg} \text {; Pantothenic acid, } 6.4 \mathrm{mg} \text {; Pyridoxine, } 1.97 \mathrm{mg} \text {; Niacin, } 28 \mathrm{mg} \text {; Vit } \\
\text { B12, } 0.008 \mathrm{mg} \text {; Choline, } 320 \mathrm{mg} \text {; Folic acid, 0.38 mg; Mn, } 60 \mathrm{mg} \text {; Fe, } 60 \mathrm{mg} \text {; Zn, } 51.74 \mathrm{mg} \text {; Cu, } 4.8 \mathrm{mg} \text {; } \\
\text { I, } 0.69 \mathrm{mg} \text {; Se, } 0.16 \mathrm{mg} \text {. * The values were calculated from NRC (1994). }\end{array}$} \\
\hline
\end{tabular}

Table 2: Chemical composition of pomegranate peel (g/kg DM, except DM g/kg fresh base)

\begin{tabular}{cccccc}
\hline & DM & CP & NDF & ADF & ASH \\
\hline 1-Fresh pp & 962 & 36 & 208 & 151 & 54 \\
2-Dried pp \% & 94.7 & 3.37 & 18.2 & 12.6 & 4 \\
\hline
\end{tabular}

where: $\mathrm{PP}=$ pomegranate peel, $\mathrm{DM}=$ dry matter, $\mathrm{CP}=$ crude protein, $\mathrm{NDF}=$ neutral detergent fiber

$\mathrm{ADF}=$ acid detergent fiber. 1- (Mirzaei-Aghsaghali et al, 2011), 2- (Taher-Maddah et al., 2012)

\section{Productive performance:}

Body weight and feed consumption were measured biweekly; while mortality rate were recorded daily. Body weight gain, feed conversion (g feed intake/g body weight gain) and mortality rate percent were calculated at the end of the experiment. 


\section{Egg production and egg quality traits:}

Egg number were recorded daily and weighed to calculate egg mass throughout the experiment egg mass $=$ average egg number/ day $\mathrm{X}$ average egg weight $(\mathrm{g})$. A total of 24 eggs ( 3 eggs/treatment) were collected from every treatment at two periods of time (16 and 22 weeks of age) to estimate egg quality parameters in poultry breeding laboratory as egg weight $(\mathrm{g})$, egg length $(\mathrm{cm})$, egg diameter $(\mathrm{mm})$, yolk weight (g), yolk diameter (mm), yolk color, albumin \%, shell weight $(\mathrm{g})$ and shell thickness $(\mathrm{mm})$. Albumen and yolk heights and widths were measured for each egg. Then yolk index was calculated using the following formula according to Romanoff and Romanoff (1949): YI= YH / $\mathrm{YD} \times 100$

Where: YI: yolk index. YH: yolkheight. YD: yolk diameter.

\section{Blood samples and physiological parameters:}

Three birds from each treatment at the end of the experiment were randomly chosen in order to slaughter, blood were collected in heparinized tubes and centrifuged at $3000 \mathrm{rpm}$ for 15 minutes and stored frozen at $-20{ }^{\circ} \mathrm{C}$ until the time to analysis. Blood plasma glucose $(\mathrm{mg} / \mathrm{dl})$, total protein $(\mathrm{mg} / \mathrm{dl})$, cholesterol $(\mathrm{mg} / \mathrm{dl})$ were determined according to Richmond (1973), LDL (mg/dl), HDL (mg/dl) , Aspartate Amino Transferase AST $(\mathrm{U} / \mathrm{ml})$, Alanine Amino Transferase ALT (U/ml) were assayed by the method of Reitman and Frankel (1957), TAOC $(\mathrm{mm} / \mathrm{l})$, uric acid and creatinine $(\mathrm{mg} / \mathrm{dl})$ were determined using chemical kits at poultry breeding laboratory according to Aggoor et al. (2000).

After slaughtering birds were weighed then defthired and weighed after that the carcass weight were measured. Liver, spleen, intestine and heart were measured byelectric scale and relative weights were calculated as a percentage of the life body weight.

\section{Microbiological analyses:}

A total number of 12 samples from the small intestine were taken. The small intestine was tied with cotton third in two different places and cut it between the tided area then resaved in saline wateruntil it reach to microbiology laboratory at animal health research institute. The samples were plated for enumeration of total bacterial count (TBC), Coliform counts, and Enterobacteriaceae counts (Gilbert et al, 2000). All the samples were evaluated using $3 \mathrm{M}^{\mathrm{TM}}$ Petrifilm ${ }^{\mathrm{TM}}$ total bacterial count plates, coliform count plates, and Enterobacteriaceae count plates (3M Microbiology, St. Paul, MN, USA) according to the instructions of the manufacturer. Intestine samples were after that diluted by sterile distilled water (typically from 1:50 to
1:200) to enable colony enumeration. The diluted intestine sample was transferred to a sterile $3 \mathrm{M}$ filtered homogenizer bag and homogenized for three minutes using a Stomacher machine (PBI International, Milan, Italy). The contents were allowed to settle, and then $1 \mathrm{~mL}$ of the liquid suspension was plated onto the appropriate Petrifilm ${ }^{\mathrm{TM}}$ according to the instructions of the manufacturer. The plates were incubated in stacks of no more than 20 plates at $35 \pm 1{ }^{\circ} \mathrm{C}$ for 48 hours for the aerobic count plates and for 24 hours for coliform and enterobacteriaceaecount plates.

\section{Thiobarbituric acid reactive substances} (TBARS) measurement:

The 2-thiobarbituric acid test (TBA) was used to determine the extent of lipid oxidation in samples. The method for analysis was described by $\mathrm{Du}$ and Ahn (2002) as follow: five grams sample was weighed into a $50 \mathrm{ml}$ test tube and homogenize (type PT 10/35) 13 for at the highest speed. One milliliter of the homogenate meat was transferred to test tube $(3 \times 100 \mathrm{~mm})$, and butylated hydroxyanisole $(50 \mu \mathrm{l} ; 7.2 \%)$ and TBA-trichloroacetic acid (TCA) (15 mm TBA$15 \% 2 \mathrm{ml}$ TCA) were added. The mixture was vortexed, incubated in a boiling water bath for $15 \mathrm{~min}$ to develop color, then cooled in cold water for $10 \mathrm{~min}$, vortexed again, and centrifuged for $15 \mathrm{~min}$ at $2.500 \mathrm{xg}$. The absorbance of the resulting supernatant solution was determined at $531 \mathrm{~nm}$ against a blank containing $1 \mathrm{ml}$ of deionized distilled water (DDW) and $2 \mathrm{ml}$ of TBA-TCA solution. The amounts of TBA-reactive substance (TBARS) were expressed as milligrams of malonaldehyde per kilogram of meat.

\section{Total phenolics:}

Samples were analyzed for total phenolic using the Folin-Ciocalteus (F-C) assay (Escarpa and Gonzalez, 2001) with slight modifications. Five gram of cooked patty was homogenized with $25 \mathrm{ml}$ of $70 \%$ acetone and kept overnight for extraction at refrigeration temperature. Suitable aliquots of extracts were taken in a test tube and the volume was made to $0.5 \mathrm{ml}$ with distilled water followed by the addition of 0.25 $\mathrm{ml} \mathrm{F-C} \mathrm{(1N)} \mathrm{reagent} \mathrm{and} 1.25 \mathrm{ml}$ sodium carbonate solution (20\%). The tubes were vortexed and the absorbance recorded at $725 \mathrm{~nm}$ by using spectrophotometer (model: UV-VIS 5704 SS, ECIL, Hyderabad, India) after $40 \mathrm{~min}$. The amount of total phenolics was calculated as tannic acid equivalent from the calibration curve using standard acid solution $(0.1 \mathrm{mg} / \mathrm{ml})$.

\section{Statistical analysis:}

The data were statistically analyzed using the general linear model procedure described by 
Costate, (1986). The linear model included the main effect of PPP or BHT and age.

$Y i j=\mu+A i+T j+e i j$

Where: $Y=$ response variable $\mu=$ overall mean $\mathrm{Ai}=$ age $\mathrm{Tj}=$ treatments $\mathrm{eij}=$ error, normally distributed. The statistical significant was declared at $(\mathrm{P} \leq 0.05)$. Differences among means were tested using Duncun`s multiple range test (Duncun, 1955).

\section{RESULT AND DISSECTION}

From the data in Table (3) it could be observed that birds fed on diet supplemented with 10 and $15 \mathrm{~g} P P P / \mathrm{kg}$ diet had significant $(\mathrm{P} \leq 0.01)$ increase body weight gain $(\mathrm{BWG})$ 267.7, $271.3(\mathrm{~g})$ compared to BHT supplemented diet and the control group $264(\mathrm{~g})$ respectively. While, there were a significant $(\mathrm{P} \leq 0.05)$ decrease in feed consumption (Fi) and feed conversion $(\mathrm{Fc})$ in all treated groups. However, Saki et al.
(2014) mentioned that there were no significant increase onBWG, Fi and $\mathrm{Fc}$ to laying hensfed on pomegranate seed pulp (PSP) but it had higher BWG than the control group. Similar to Rajani et al. (2011) who found that broiler BW is not affected by pomegranate peel treatment. Treated normal rats with pomegranate peel extract resulted in non-significant increase in body weight after4-weeks (Enas, 2004). On the contrary, Lin et al., (1989) and Wang et al. (1997) who noted that BHA/BHT and ethoxyquin had significant increase in body weight of broilers. Mortality rate percent was lowerd in significantly in birds diets supplemented with $15 \mathrm{~g} \mathrm{PPP} / \mathrm{kg}$ diet and BHT compared with groups fed on $10 \mathrm{~g}$ PPP $/ \mathrm{kg}$ diet and the control. This result is in agreement with Rajani et al. (2011) who found that antioxidant feed additives reduced ascites mortality in comparison to control group $(\mathrm{P} \leq 0.05)$.

Table 3. Productive performance as affected by addition of pomegranate peel powder (PPP) and butylated hydroxyle toluene (BHT) during the experiment period

\begin{tabular}{|c|c|c|c|c|c|}
\hline \multirow{2}{*}{ Items } & T1 & T2 & T3 & T4 & \multirow{2}{*}{ Sig. } \\
\hline & \multicolumn{4}{|c|}{ Initial body weight( 11 wk) } & \\
\hline & $257 \pm 3.34$ & $\begin{array}{l}257 \pm 3.33 \\
\mathbf{1 2 - 1 3} \text { wks }\end{array}$ & $256 \pm 3.34$ & $256 \pm 3.34$ & NS \\
\hline Bw (g) & $260 \pm 0.578$ & $261 \pm 0.581$ & $262 \pm 0.560$ & $260 \pm 0.545$ & NS \\
\hline Fi(g/bird) & $490.3^{\mathrm{a}} \pm 0.334$ & $477^{\mathrm{b}} \pm 0.578$ & $460.67 \mathrm{~d} \pm 0.333$ & $467.67^{\mathrm{c}} \pm 0.340$ & $* * *$ \\
\hline Fc(gfeed/gain) & $1.89^{\mathrm{a}} \pm 0.005$ & $\begin{array}{r}1.83^{\mathrm{b}} \pm 0.003 \\
\mathbf{1 4 - 1 5} \text { wks }\end{array}$ & $1.76^{\mathrm{d}} \pm 0.004$ & $1.80^{\mathrm{c}} \pm 0.004$ & $* * *$ \\
\hline Bw $(\mathbf{g})$ & $260.3^{\mathrm{b}} \pm 0.334$ & $263^{\mathrm{b}} \pm 0.578$ & $271^{\mathrm{a}} \pm 2.335$ & $263^{\mathrm{b}} \pm 0.578$ & $* *$ \\
\hline Fi(g/bird) & $503^{\mathrm{b}} \pm 0.578$ & $512^{\mathrm{a}} \pm 0.578$ & $502.67^{\mathrm{b}} \pm 1.730$ & $494.66^{\mathrm{c}} \pm 1.730$ & $* * *$ \\
\hline Fc(gfeed/gain) & $1.93^{\mathrm{a}} \pm 0.003$ & $\begin{array}{r}1.95^{\mathrm{a}} \pm 0.004 \\
\mathbf{1 6 - 1 7} \mathrm{wks}\end{array}$ & $1.85^{\mathrm{c}} \pm 0.016$ & $1.88^{\mathrm{b}} \pm 0.003$ & $* * *$ \\
\hline Bw $(\mathbf{g})$ & $264.67^{\mathrm{c}} \pm 0.334$ & $269^{\mathrm{b}} \pm 0.579$ & $273^{\mathrm{a}} \pm 1.01$ & $266^{\mathrm{c}} \pm 0.576$ & $* * *$ \\
\hline Fi(g/bird) & $612^{\mathrm{a}} \pm 0.578$ & $585.7^{\mathrm{b}} \pm 0.046$ & $562.3^{\mathrm{c}} \pm 0.879$ & $552^{\mathrm{d}} \pm 0.579$ & $* * *$ \\
\hline Fc(gfeed/gain) & $2.31^{\mathrm{a}} \pm 0.003$ & $\begin{array}{r}2.18^{\mathrm{b}} \pm 0.004 \\
\mathbf{1 8 - 1 9} \text { wks }\end{array}$ & $2.06^{\mathrm{d}} \pm 0.004$ & $2.08^{c} \pm 00003$ & $* * *$ \\
\hline $\mathbf{B w}(\mathbf{g})$ & $265.33^{\mathrm{d}} \pm 0.303$ & $270.3^{\mathrm{b}} \pm 0.345$ & $274.2^{\mathrm{a}} \pm 0.334$ & $267^{\mathrm{c}} \pm 0.578$ & $* * *$ \\
\hline Fi(g/bird) & $689^{\mathrm{a}} \pm 0.578$ & $681^{\mathrm{b}} \pm 0.577$ & $665^{\mathrm{c}} \pm 1.730$ & $663^{\mathrm{d}} \pm 1.734$ & $* * *$ \\
\hline Fc(gfeed/gain) & $2.60^{\mathrm{a}} \pm 0.004$ & $\begin{array}{c}2.52^{\mathrm{b}} \pm 0.003 \\
\mathbf{2 0 - 2 2} \mathbf{w k s}\end{array}$ & $2.43^{\mathrm{d}} \pm 0.004$ & $2.49^{c} \pm 0.003$ & $* * *$ \\
\hline Bw (g) & $270^{\mathrm{b}} \pm 0.578$ & $275^{\mathrm{a}} \pm 0.330$ & $276.3^{\mathrm{a}} \pm 0.329$ & $268^{\mathrm{c}} \pm 0.329$ & $* * *$ \\
\hline Fi(g/bird) & $720.3 \pm 0.879$ & $717.7 \pm 0.329$ & $652.0 \pm 33.538$ & $688.3 \pm 0.334$ & NS \\
\hline Fc(gfeed/gain) & $2.67^{\mathrm{a}} \pm 0.003$ & $\begin{array}{r}2.61^{\mathrm{a}} \pm 0.004 \\
\mathbf{1 1 - 2 2} \mathbf{w k s}\end{array}$ & $2.36^{\mathrm{b}} \pm 0.004$ & $2.57^{\mathrm{a}} \pm 0.003$ & $*$ \\
\hline Bw (g) & $264.04^{\mathrm{C}} \pm 1.283$ & $267.7^{\mathbf{B}} \pm 1.853$ & $271.3^{\mathbf{A}} \pm 2.257$ & $264.9^{C} \pm 1.223$ & $* *$ \\
\hline Fi(g/bird) & $602.9^{\mathbf{A}} \pm 0.689$ & $594.7^{\mathbf{B}} \pm 0.522$ & $568.5^{\mathrm{D}} \pm 7.64$ & $573.13^{\mathrm{C}} \pm 1.024$ & $* * *$ \\
\hline Fc(gfeed/gain) & $2.28^{\mathrm{A}} \pm 0.010$ & $2.22^{\mathbf{B}} \pm 0.009$ & $2.10^{\mathrm{D}} \pm 1.002$ & $2.16^{\mathrm{C}} \pm 0.002$ & $* * *$ \\
\hline Mortality\% & 4.44 & 4.44 & 2.22 & 2.22 & \\
\hline
\end{tabular}

a-d treatments within the (row-wise) with different superscripts are significantly different ( $\mathrm{p} \leq 0.05$ ). A-D within the same time (column-wise) with different superscripts are significantly different $(\mathrm{p} \leq 0.05)$; each value is a mean $\mathrm{SE}$ of three replicates.Bw= body weight $(\mathrm{g}), \mathrm{FI}=$ feed intake $(\mathrm{g}), \mathrm{FC}=$ feed conversion $(\mathrm{g})$

Data in Table (4) concluded that there were significant effects on yolk diameter and shell weight. Internal egg quality from birds receiving BHT contained a significantly $(\mathrm{P} \leq 0.005)$ lower of yolk diameter. While, it was significantly $(\mathrm{P} \leq 0.005)$ higher in shell weight than the control group and the other experimental groups. 
Table 4. Egg quality as affected by addition of pomegranate peel powder (PPP) and butylated hydroxyle toluene (BHT) during 2 periods of time (16 \& 21 wks of age) and their interactions

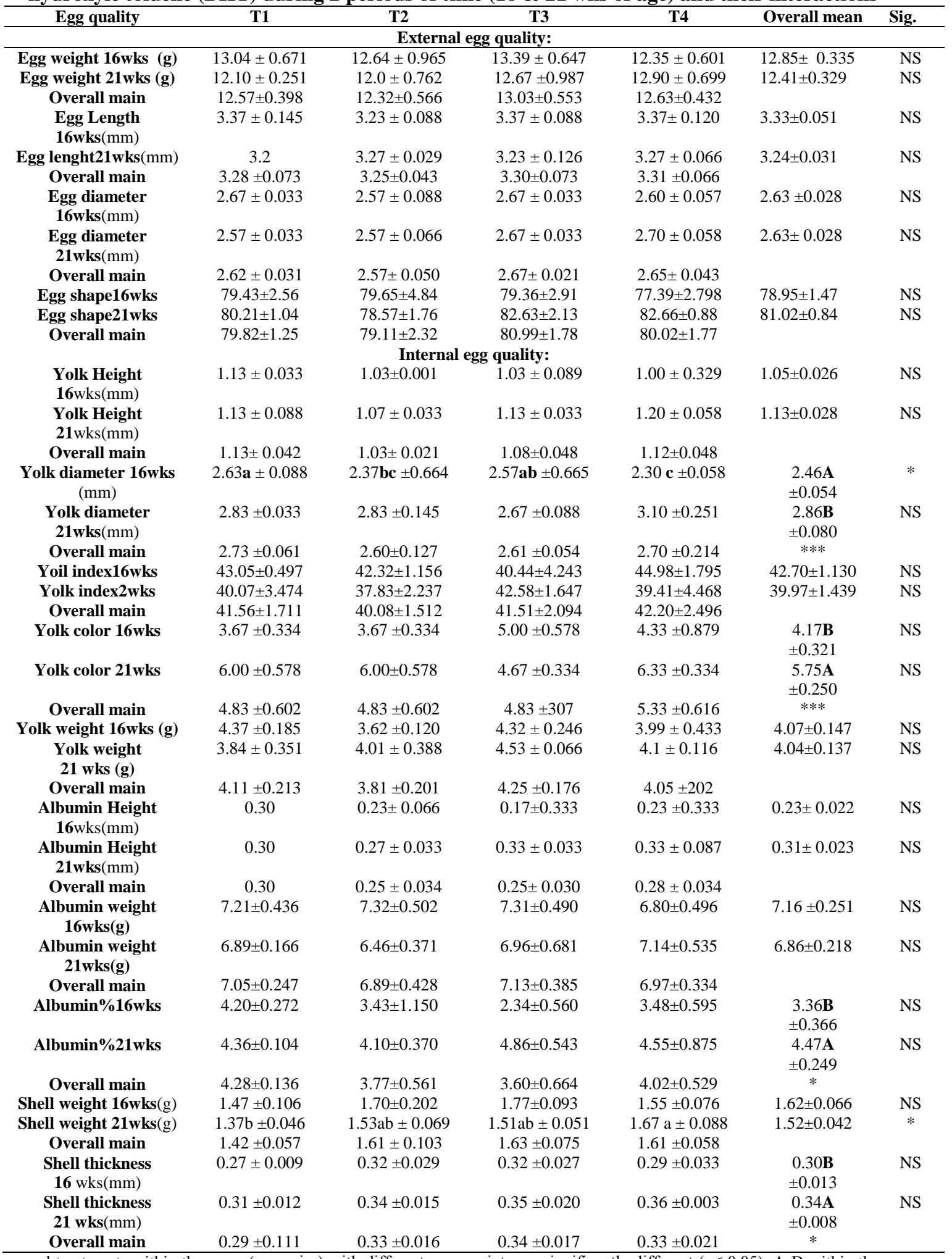

a-d treatments within the same (row-wise) with different superscripts are significantly different $(\mathrm{p} \leq 0.05)$. A-D within the same time (column-wise) with different superscripts are significantly different $(\mathrm{p} \leq 0.05)$; each value is a mean $\mathrm{SE}$ of three replicates.

From data in Table (5) it could be concluded that there were significant in plasma parameters as effect by supplemented diet with PPP and BHT. Plasma cholesterol, HDL, LDL, total lipids, AST, ALT, TAOC, createnine, uric acid and glucose were significantly $(\mathrm{P} \leq 0.001)$ decreased in all treated groups compared with the control one (Table 5). This result in agreement with Enas (2004) who investigated the role of Punicagrantum powder peel aqueous extract (PGPPE). She found that there was a significant decrease in plasma glucose in normal 
rats treated with PPPE. While, plasma total protein were significantly $(\mathrm{P} \leq 0.05)$ increased in treated groups compared with the control. On the other hand, Fatma, (2009) demonstrated that hypercholestrolemic rats (positive control) administrated with PPP (5, 10 and $15 \%)$ and its extracts (1,2 and 3\%) significantly decreased total cholesterol and HDL. While, PPP administration were significantly higher than the negative control.

Table 5. plasma parameters as affected by addition of pomegranate peel powder (ppp) and butylated hydroxyle toluene (BHT)

\begin{tabular}{lccccc}
\hline PLASMA & T1 & T2 & T3 & T4 & Sig. \\
\hline Cholesterol(mg/dl) & $216.52 \mathrm{a} \pm 32.160$ & $147.27 \mathrm{~b} \pm 2.751$ & $144.70 \mathrm{~b} \pm 7.350$ & $142.55 \mathrm{~b} \pm 2.325$ & $*$ \\
HDL (mg/dl) & $47.72 \mathrm{a} \pm 1.503$ & $39.32 \mathrm{~b} \pm 2.243$ & $34.44 \mathrm{~b} \pm 1.40$ & $33.44 \mathrm{~b} \pm 1.306$ & $* *$ \\
LDL (mg/dl) & $113.13 \mathrm{a} \pm 3.844$ & $108.15 \mathrm{ab} \pm 4.95$ & $97.70 \mathrm{bc} \pm 2.861$ & $90.13 \mathrm{c} \pm 2.295$ & $* *$ \\
TL (mg/dl) & $913 \mathrm{a} \pm 11.857$ & $658.48 \mathrm{~b} \pm 23.23$ & $560.28 \mathrm{c} \pm 9.047$ & $516.77 \mathrm{c} \pm 0.295$ & $* * *$ \\
AST (U/ml) & $0.880 \mathrm{a} \pm 0.027$ & $0.69 \mathrm{~b} \pm 0.043$ & $0.52 \mathrm{c} \pm 0.010$ & $0.46 \mathrm{c} \pm 0.018$ & $* * *$ \\
ALT (U/ml) & $0.87 \mathrm{a} \pm 0.032$ & $0.66 \mathrm{~b} \pm 0.023$ & $0.62 \mathrm{~b} \pm 0.070$ & $0.50 \mathrm{c} \pm 0.018$ & $* * *$ \\
TAOC(mM/L) & $1.65 \mathrm{a} \pm 0.082$ & $1.23 \mathrm{~b} \pm 0.152$ & $0.98 \mathrm{~b} \pm 0.025$ & $0.99 \mathrm{~b} \pm 0.031$ & $* *$ \\
Albumen(mg/dl) & $3.54 \pm 0.476$ & $4.20 \pm 0.274$ & $4.05 \pm 0.44$ & $4.43 \pm 0.135$ & $\mathrm{NS}$ \\
Creatnine(mg/dl) & $1.09 \mathrm{a} \pm 0.035$ & $0.88 \mathrm{~b} \pm 0.031$ & $0.73 \mathrm{c} \pm 0.006$ & $0.63 \mathrm{c} \pm 0.018$ & $* * *$ \\
TP (mg/dl) & $6.52 \mathrm{~d} \pm 0.249$ & $7.83 \mathrm{c} \pm 0.343$ & $8.52 \mathrm{~b} \pm 0.036$ & $9.26 \mathrm{a} \pm 0.205$ & $* * *$ \\
Uric acid (mg/dl) & $5.90 \mathrm{a} \pm 0.150$ & $4.85 \mathrm{~b} \pm 0.091$ & $4.27 \mathrm{c} \pm 0.075$ & $3.91 \mathrm{c} \pm 0.068$ & $* * *$ \\
Glucose (mg/dl) & $97.43 \mathrm{a} \pm 0.859$ & $87 \mathrm{~b} \pm 0.882$ & $77.88 \mathrm{c} \pm 1.282$ & $72.52 \mathrm{~d} \pm 2.127$ & $* * *$ \\
\hline
\end{tabular}

a-d treatments within the same (row-wise) with different superscripts are significantly different $(\mathrm{p} \leq 0.05)$.

Data in Table (6) showed that there were no significant effects of PPP and BHT on bird's weights before and after slaughtered or the relative organs weights. While groups fed on diet contained PPP and BHT were significantly higher than control group on defithered birds weight also there were a significant decrease in relative heart relative weight in group fed 15 $\mathrm{g} / \mathrm{kg}$ PPP compared to other groups. These results are in agreement with ChalfounMounayar et al. (2012) who found that adding pomegranate molasses or juice to mice drinking water $(4 \mathrm{ml} / \mathrm{l})$ during 11 weeks leading to a significant decrease in the heart, lungs, and the liver. Rao et al. (2000) showed that short-term or subchronic exposure to BHT affects the liver of chickens, also showing histopathological changes in this organ.

Data in Table (7) concluded that there were no significant effects of PPP and BHT on micro bacterial count in the small intestine. This results are in contrary with Yahia et al. (2011) who concluded that combinations of pomegranate rind extract (PRE) with metal salt $\mathrm{ZnSO} 4$ and Vitamin C (1:1:1)exhibit enhanced antimicrobial effects against both Gram positive (Bacillus subtilis, Staphylococcus spp. and Brucella spp.) and Gram negative (E. coli).

Table 6. Bird and carcass weightas affected by addition of pomegranate peel powder (PPP) and butylated hydroxyle toluene (BHT)

\begin{tabular}{lccccc}
\hline traits & T1 & T2 & T3 & T4 & Sig. \\
\hline LBW $(\mathbf{g})$ & $265.67 \pm 9.035$ & $293 \pm 26.60$ & $251.67 \pm 4.809$ & $264.33 \pm 8.197$ & $\mathrm{NS}$ \\
SBW $(\mathbf{g})$ & $257.67 \pm 8.116$ & $284 \pm 25.610$ & $244.33 \pm 5.818$ & $258 \pm 7.237$ & $\mathrm{NS}$ \\
DFEW & $223 \mathrm{~b} \pm 7.01$ & $276 \mathrm{a} \pm 26.59$ & $226 \mathrm{~b} \pm 4.046$ & $236.33 \mathrm{ab} \pm 6.936$ & $* *$ \\
CARCASS & $203.1 \pm 9.28$ & $241.3 \pm 34.15$ & $123.87 \pm 60.69$ & $167.67 \pm 26.01$ & $\mathrm{NS}$ \\
LIVER\% & $3.01 \pm 0.566$ & $2.54 \pm 0.474$ & $3.18 \pm 0.377$ & $3.56 \pm 0.230$ & $\mathrm{NS}$ \\
SPLEEN\% & $0.18 \pm 0.026$ & $0.13 \pm 0.052$ & $0.39 \pm 0.289$ & $0.29 \pm 0.058$ & $\mathrm{NS}$ \\
INT.\% & $3.42 \pm 0.158$ & $3.54 \pm 0.428$ & $2.99 \pm 0.428$ & $3.89 \pm 0.386$ & $\mathrm{NS}$ \\
HEART\% & $0.74 \mathrm{a} 0.052$ & $0.75 \mathrm{a} \pm 0.069$ & $0.54 \mathrm{~b} 0.045$ & $0.87 \mathrm{a} \pm 0.054$ & $*$ \\
\hline
\end{tabular}

a-d treatments within the same (row-wise) with different superscripts are significantly different ( $\mathrm{p} \leq$ $0.05)$.

Table 7. micro-bacterial count as affected by addition of pomegranate peel powder (PPP) and butylated hydroxyle toluene (BHT)

\begin{tabular}{lccccc}
\hline MICRO & T1 & T2 & T3 & T4 & Sig. \\
\hline TBC & $1.673 \times 10^{5}$ & $2.441 \times 10^{6}$ & $1.716 \times 10^{6}$ & $1787 \times 10^{6}$ & NSP $=0.6$ \\
Entrobac. & $8.00 \times 10^{2}$ & $2.053 \times 10^{3}$ & $1.217 \times 10^{4}$ & $5.900 \times 10^{3}$ & NSP $=0.5$ \\
Coliform c. & $1.20 \times 10^{2}$ & $1.880 \times 10^{2}$ & $1.233 \times 10^{3}$ & $1.40 \times 10^{2}$ & NSP $=0.1$
\end{tabular}

The means within the same row with at least one common letter, do not have significant difference $(\mathrm{P}>0.05)$. 
Data in Table (8) concluded that there was significant increase in total phenolics. While, the TBARS values was significantly decreased in group fed $15 \mathrm{mg} \mathrm{PPP} / \mathrm{kg}$ diet compared with BHT supplemented diet and the control group. The TBARS values significantly increased affected by the storage period. These results in agreement with Rajani et al. (2011) who mentioned that pomegranate peel treatment being the most effective $(\mathrm{P} \leq 0.01)$ introducing the Malondialdehyde (MDA) occurrence in meat of birds. MDA occurrence in meat is a popular assessment of lipid oxidation (Botsoglou et al., 1994). Although there was no study examining the antioxidative effect of dietary PP on stored meat, Swamy et al. (2011) reported the lower MDA in fresh liver samples of rats fed PP extract $(25 \mathrm{mg} / \mathrm{d}$ polyphenols equivalent). The PP ability to lower MDA levels could be explained by antioxidant compounds including, (a) ellagitannins, a precursor of ellagic acid, which has been found to have antioxidative properties (Osawa et al., 1987; Mass et al., 1991). Also, Zeweil et al. (2013) reborted that lipid peroxide (malondialdehyde) levels decreased significantly to reach around $54 \%$ of the heat stressed bucks,' value of PP were 1.5, 3.0 and $4.5 \%$ of PP dietary used.

Table 8. Thiobarbituric acid reactive substances (TBARS) values (mg ofmalonaldehyde/kg meat) and the total phenolic content of (tannic acid eq) ug/g as affected by addition of pomegranate peel powder (PPP) and butylated hydroxyle toluene (BHT) during frozen storage at $-20 \mathrm{C}$

\begin{tabular}{cccccc}
\hline $\begin{array}{c}\text { Treatments/Storage } \\
\text { period (month) }\end{array}$ & $\mathbf{T 1}$ & $\mathbf{T 2}$ & $\mathbf{T 3}$ & T4 & Sig. \\
\hline $\mathbf{0}$ & $0.307 \pm 0.08$ & $0.271 \pm$ & $0.103 \pm$ & $0.18 \pm 0.05 \mathrm{abA}$ & NS \\
$\mathbf{1}$ & $\mathrm{cA}$ & $0.08 \mathrm{bcA}$ & $0.03 \mathrm{aA}$ & & \\
& $0.635 \pm$ & $0.266 \pm$ & $0.098 \pm$ & $0.388 \pm 0.17 \mathrm{bAB}$ & $*$ \\
$\mathbf{2}$ & $0.09 \mathrm{cB}$ & $0.03 \mathrm{bA}$ & $0.01 \mathrm{aA}$ & & \\
& $1.016 \pm$ & $0.485 \pm$ & $0.140 \pm$ & $0.498 \pm 0.31 \mathrm{bB}$ & $*$ \\
$\mathbf{3}$ & $0.03 \mathrm{cC}$ & $0.16 \mathrm{bB}$ & $0.03 \mathrm{aA}$ & & \\
& $1.272 \pm$ & $0.763 \pm$ & $0.203 \pm$ & $0.896 \pm 0.12 \mathrm{bC}$ & $*$ \\
Total phenolics & $0.13 \mathrm{cD}$ & $0.16 \mathrm{bC}$ & $0.04 \mathrm{aB}$ & & \\
(as tannic acid eq)ug/g & $153 \pm 19.55$ & $192 \pm 10.60 \mathrm{~b}$ & $225 \pm 10.60$ & $160 \pm 18.16 \mathrm{c}$ & $*$
\end{tabular}

(as tannic acid eq)ug/g

a-d treatments within the same storage conditions (row-wise) with different superscripts are significantly different $(\mathrm{p} \leq 0.05)$. A-D storage conditions within the same treatment (column-wise) with different superscripts are significantly different $(\mathrm{p} \leq 0.05)$; each value is a mean SE of three replicates.

\section{REFERENCES}

Abdel Moneim A. E., M. A.Dkhil and S. AlQuraishy, 2011. Studies on the effect of pomegranate (Punicagranatum) juice and peel on liver and kidney in adult male rats.JMPR.In Press.Adha.

Aggoor, F.A.M., Attia, Y.A. and E.M.A. Qota, 2000. A study on the energetic efficiency of different fat sources and levels in broiler chick vegetable diets. J. Agric. Sci. Mansoura Univ., 25, 801-820.

Botsoglou, N.A., D. J. Fletouris, G. E. Papageorgiou, V. N. Vassilopoulos, Mantis, A.J. and A. G. Trakatellis, 1994. Rapid, sensitive, and specific thiobarbituric acid method for measuring lipid peroxidation in animal tissue, food and feedstuff samples. J. Agric. Food Chem. 42, 1931-1937.

Chalfoun-Mounayar, A., R. Nemr, P. Yared, S. Khairallah and R. Chahine, 2012. Antioxidant and weight loss effects of pomegranate molasses. Journal of Applied Pharmaceutical Science 02 (06); 45-50.

Costate computer program copy right , 1986. Version 3.03 copy right software.
Du, M. and D.U. Ahn, 2002. Effect of antioxidants on the quality of irradiated sausages prepared with turkey thigh meat. Poultry Sci. 81, 1251-1256.

Duncan's, D.B., 1955. Multiple range and multiple F- test. Biometrics, 11: 1 -42.

Enas A. M. Khalil, 2004. Antidiabetic effect of an aqueous extract of Pomegranate (Punicagranatum L.) peels in normal and alloxan diabetic rats. The Egyptian Journal of Hospital Medicine Vol., 16: 92 - 99

Escarpa, A. and M.C. Gonzalez, 2001. Approach to the content of total extractable phenolic compounds from different food samples by comparison of chromatographic and spectrophotometric methods. Anal. Chim. Acta. 427, 119-127.

European Food Safety Authority, 2012. Reevaluation of butylated hydroxytoluene BHT (E 321) as a food additive.EFSA Journal, 10(3):2588

Fatma, L.A. Hossin , 2009. Effect of pomegranate (Punicagrantum) peel and it's extract on obese hypercholesterolemic rats. Pakistan Journal of Nutition 8(8):1251-1257. 
Gracious Ross R, S. Selvasubramanian , S. Jayasundar , 2011 .Immunomodulatory activity of Punicagranatum in rabbits--a preliminary study. J. Ethnopharmacol.78(1):85-87.

Gilbert, R.J., D.E. Louvois, J. Donovan, T. Little, C. Nye and K. Ribeiro, 2000. Guidelines for the microbiological quality of some ready-to-eat foods sampled at the point of sale. Commun Dis Public Health.3:163-7.

Jones S., D.W.L. Ma, F.E. Robinson, C.J. Field and M.T. Clandinin, 2000. Isomers of conjugated linoleic acid (CLA) are incorporated into egg yolk lipids by CLA-fed laying hens. J. Nutr. 130, 2002-2005.

Kassab. A., J.T. Abrams and D.W. Sainsbury , 1979. The effects of antioxidants on the content of polyunsaturated fatty acids in the hen's egg. Int. J. Vitam. Nutr. Res. ;49(2):199-209.

Li, Y.; C. Guo, J. Yang, J. Wei, J. Xu and S. Cheng, 2006. Evaluation of antioxidant properties of pomegranate peel extract in comparison with pomegranate pulp extract. Food Chemistry 96; 254-260

Lin, C.F., A. Asghar, J.I. Gray, D.J. Buckley, A.M. Booren, R.L. Crackel and C.J. Flegal, 1989. Effects of oxidized dietary oil and antioxidant supplementation on broiler growth and meat stability. Br. Poult. Sci. 30, 855-864.

Marinova E.M and N.V. Yanishlieva, 1997. Antioxidative activity of extracts from selected species of the family Laminacae in sunflower oil. Food Chem. 58: 245.

Mass, J.L., G.L. Galletta, and G.D. Stoner, 1991. Ellagic acid, an anticarcinogen in fruits, especially in strawberries. Hort. Sci. 26, 1014.

Mirzaei-Aghsaghali, A., N. Maheri-sis, H. Mansouri, M. E. Razeghi, 2011. Evaluating potentialnutritive value of pomegranate processing by-products for ruminants using in vitro gasproduction technique.ARPN Journal of Agricultural and Biological Science, 6,(6).45-51.

Negi, P.S. and G.K. Jayaprakasha, 2003. Antioxidant and antibacterial activities of Punicagranitum peel extracts. J. Food Sci. 68, 1473-1477.

Negi, P.S., G.K. Jayaprakasha and B.S. Jena, 2003. Antioxidant and antimutagenic activities of pomegranate peel extracts. Food Chem. 80, 393-397.

NRC, National Research Council, 1994. Nutrient requirements of poultry. $9^{\text {th }}$ ed. National Academic Press, Washington DC, USA.

Osawa, T., A. Ide, J.D. Su, and M. Namiki ,1987. Inhibition of lipid peroxidation by ellagic acid. J. Agric. Food Chem. 35, 808812 .
Rajani, J., M.A. KarimiTorshizi and Sh. Rahimi, 2011. Control of ascites mortality and improved performance and meat shelf-life in broilers using feed adjuncts with presumed antioxidant activity.Animal Feed Science and Technology 170: 239- 245.

Rao, G.V.S., K. R. Parthasarathy and A. Sundararaj, 2000. Haemorrhagic syndrome in butylated hydroxyl toluene (BHT) toxicity in broiler chicken. Indian Veterinary Journal 77, 117-119.

Reitman, S. and S. Frankel, 1957. Colorimetric method for the determination of serum glutamic pyruvic transaminase. Am. J. Clin. Pathol., 28: 56-63.

Richmond, W., 1973. Colorimetric method for the determination of plasma cholesterol. Clinic. Chem., 19: 1350-1356.

Romanoff, A.L. and A.J. Romanoff, 1949. The avian egg.New York, John Wiley and sons Inc.

Saki, A. A., M. Rabet, P. Zamani and A. Yousefi, 2014. The Effects of Different Levels of Pomegranate Seed Pulp with MultiEnzyme on Performance, Egg Quality and Serum Antioxidant in Laying Hens. Iranian Journal of Applied Animal Science 4(4), 803 808.

Salahvarzi, Y., A. Tehranifar and V. Jahanbakhsh, 2011. Relation of antioxidant and antifungal activity of different parts of Pomegranate (Punicagranatum L.) extracts with its phenolic content. Iranian Journal of Medical and Aromatic Plants, (Issue 1)

Swamy, M.S.L., S. Naveen, D. Singsit, M Naika, F. Khanum, 2011. Anti-fatigue effects of polyphenols extracted from pomegranate peel. Int. J. Integr. Biol. 11, 69-72.

Taher-Maddah, M., N. Maheri-Sis, R. Salamatdoustnobar and A. Ahmadzadeh, 2012. Comparing nutritive value of ensiled and dried pomegranate peels for ruminants using in vitro gas production technique. Annals of Biological Research, 3 (4):19421946

Wang, S.Y., W. Bottje, P. Maynard, J. Dibner and W. Shermer, 1997. Effect of Santoquin and oxidized fat on liver and intestinal glutathione in broilers.Poult. Sci. 76, 961967.

Yehia, H.M., Manal F. Elkhadragyand and A.E. Abdel Moneim, 2011. Antimicrobial activity of pomegranate rind peel extracts. African Journal of Microbiology Research 4(22), 3664-3668

Zeweil, H.S., S. ElNagar, S.M. Zahran, M.H. Ahmed and Y. El-Gindy, 2013. Pomegranate Peel as a Natural Antioxidant Boosts Bucks' Fertility under Egyptian Summer Conditions. World Rabbit Sci. 21: 33-39 


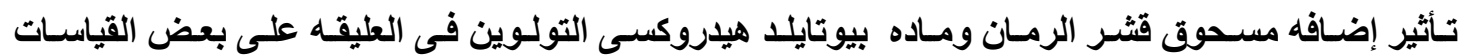

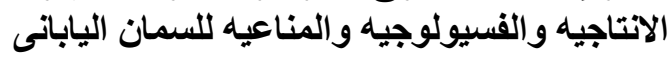

دعاء محمد محمد يس، إيهاب أحمد عبد الله، إيناس إبراهيم اسماعيل، أحمد أحمد فضل معرج بحوث الإنتاج الحيوانى،قسم بحوث تربيه الدواجن، مركز البحوث الزراعيه

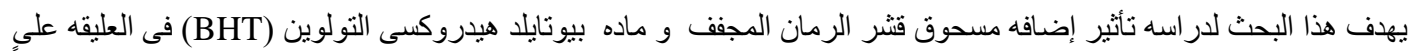

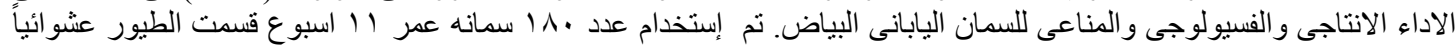

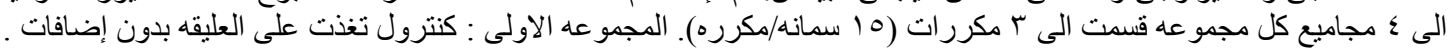

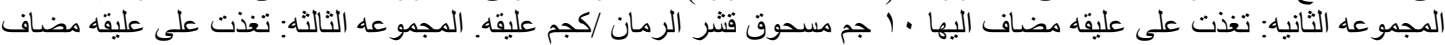

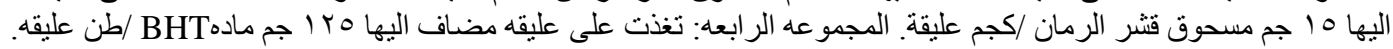
وقد تم الحصول على النتائج التاليه:

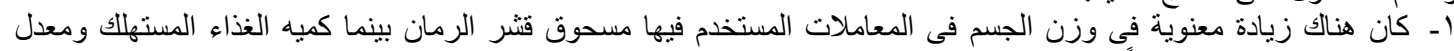

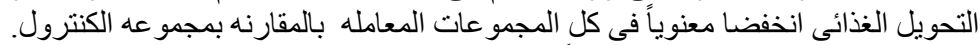

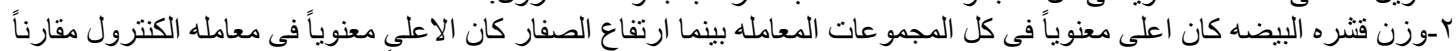

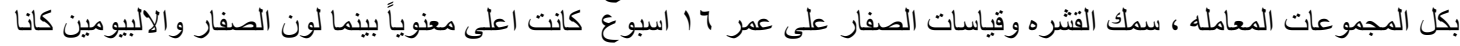

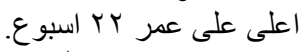

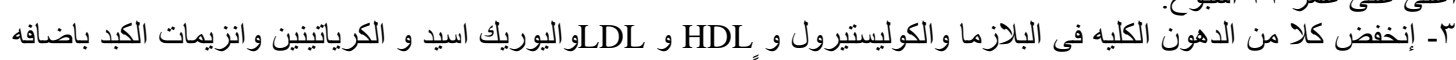

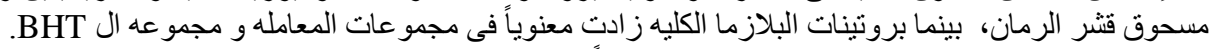

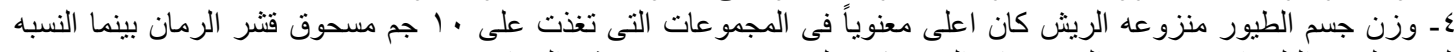

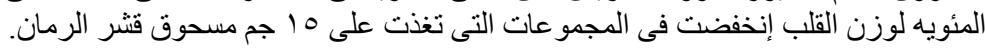

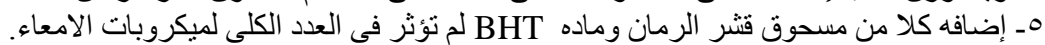

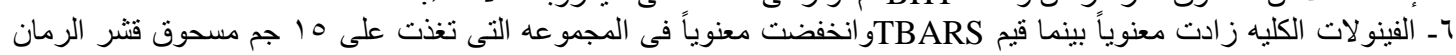

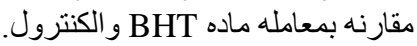

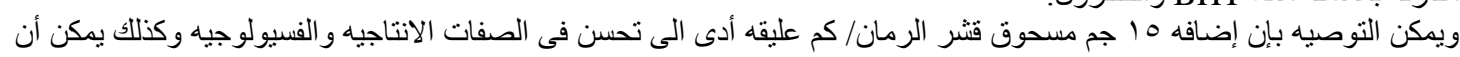
يطيل من مده حفظو وتخزين اللحم فى المبردات وحتى مو عد أستهلاكها. 